\title{
Chemistry, Biology, and the Heterogeneity of Modern Waters
}

Scholars of water argue that large-scale public water systems built with new engineering techniques in the late nineteenth and early twentieth centuries created "new water"- uniform, homogeneous, and public. ${ }^{1}$ What is not often remembered, however, is that the creation of new water depended on a continuing appraisal of the heterogeneity and specificity of waters. In building public works, engineers had to confront the specific details of particular water sources, such as location, origin, flow rate, mineral content, and other variables. Chemists and biologists working to ensure that public water met uniform health standards needed to identify and measure the biological and mineral contents of these waters. Although the groundwater that supplied the bathhouses of Mexico was not hot, not highly mineralized, and did not spring to the surface by itself, it was nevertheless incorporated into existing classifications of those kinds of waters, in recognition of its specificity and its relation to other waters. Scientists analyzed the mineral contents of artesian wellwaters, constructed theories about their geological origins, looked for microbes, and reached the conclusion that they were perfectly suitable for inclusion in homogeneous public water.

Ideas about the heterogeneity of waters also evolved due to important developments within science. At first, those who studied water were mostly chemists, but after about 1860, biologists equipped with more powerful microscopes identified organisms that caused diseases that were previously thought to derive from the waters themselves, or from the gases that emanated from them. ${ }^{2}$ With the rise of bacteriology, it became evident that cholera, yellow fever, malaria, and other diseases did not result from physical aspects of the climate, environment, and geology, but rather from organisms that grew in water. Hygiene and sanitation in public health squared off against these bacteria, in an effort to sterilize and sanitize 
public water. In this process of creating and imposing uniform standards for public water, the virtues of heterogeneous waters were sometimes forgotten.

But they were not forgotten for long. Despite the expansion of infrastructure and the shift to biological understandings of health and disease, the idea of a homogeneous, "public" water never completely dominated, neither in popular nor scientific minds. Mexico's medical community was filled with pharmacists and chemists who continued to research the content and therapeutic qualities of Mexico's many waters, and in particular, its groundwater and mineral springs. Leopoldo Río de la Loza was a central figure in the resilience of physical-chemical approaches to water and health, who, from his chair in the National Academy of Medicine and National School of Medicine, directed research and trained generations of scholars. One of his students, Eduardo Liceaga, pioneered bacteriological approaches to health in Mexico, introducing vaccinations and addressing outbreaks of yellow fever through quarantine. Liceaga rose in prominence to direct the National Health Council and other medical institutions during the ascent of bacteriology, but he maintained a deep interest in the therapeutic uses of waters, especially the physiological effects of baths and showers, and he promoted research on bathing at the National School of Medicine, at the National General Hospital that he designed and built, and at the mineral hot springs of Peñon de los Baños.

The same economic growth that spurred the construction of infrastructure and bathhouses in the Porfiriato also promoted the development of hot springs and mineral springs into medical facilities and business. Even though hot springs bathhouses such as Peñon fell into decay during the early Republican period, most Mexicans continued to hold deep-seated beliefs about the medical benefits of mineral water bathing. The idea that bathing in and drinking mineral waters was medicinal and therapeutic enjoyed a resurgence with the popular "hydropathy" movement in the 1840 os and again, in a more elite scientific form, in the late nineteenth and early twentieth centuries, even with the rising hegemony of bacteriology. A new bathhouse was built at Peñón, and Liceaga himself opened a bathhouse in Villa de Guadalupe. Furthermore, as the nineteenth century progressed, relaxation and recreation were added to the benefits ascribed to water therapy. ${ }^{3}$ So while uniform public water consolidated its presence in Mexico after 1850, it was accompanied by a booming science and business of heterogeneous waters.

\section{THE SCIENCE OF GROUNDWATER: CHEMISTRY AND BIOLOGY IN BALANCE}

By the 1850 s the rush was on in Mexico City to drill for water. The boom of artesian wells raised geological questions about groundwater. Where was it located? How did it flow? Was it connected to surface water? Sebastián Pane and his partner D. Augustin Molteni provided material from one of the first well bores to Leopoldo Río de la Loza, a chemist who studied waters, so that he could sketch the strata underlying the Valley of Mexico. ${ }^{4}$ The Ildefonso brothers and Ignacio Ortiz de 
Zarate did the same when they opened a well at the Casa de la Moneda, just off the Zocalo in $1871 .^{5}$ Technological improvements allowed engineers to discover everdeeper water-bearing strata - at 52 meters in 1858, 105 meters in 1863 , and up to 234 meters below the surface in the case of the well sunk by Carlos Pérez Rívas near the Military Hospital. Wells sunk far from the city center encountered the same strata as those outlined by the geological studies, but at different depths. ${ }^{6}$ These wells usually tapped the third aquifer from the surface, which according to Río de la Loza held the best quality water, but deeper and shallower ones were also commonly used.

Because of artesian wells, the water supply almost doubled by 1858 ; by 1883 it almost tripled.? At the same time, however, aquifer water was an unknown substance, and there was no information about where it came from, how much there was, its mineral content and quality, its relation to surface waters, or the effects of extracting it from the ground. No one knew if it was safe to drink. Mexico City's varied waters had always been conceived of as unique, their qualities associated with the places they emerged. The springs of Santa Fe were "softer," "lighter," and "thinner" than the springs at Chapultepec; the springs in the Desierto de los Leones were found to be even purer, more "crystalline." Well-drilling in the 1850 introduced new waters into the lives of Mexicans, but where did the artesian waters come from, and how did they compare to the known waters?

Noel Coley and others have shown that the modern disciplines of chemistry and medicine were formed to a significant degree through the analysis and replication of mineral waters, and this can be seen in Mexico as well. ${ }^{8}$ How scientists approached the question of health and water changed dramatically between when the first artesian well was drilled around 1850 and the completion of the Xochimilco springs aqueduct in 1910, due to a conceptual paradigm shift ushered in by the identification of microorganisms and their linkage to fermentation, putrefaction, foul smells, and disease. For millennia health had been seen as an organism's relation to the qualities and elements in its environment ("airs, waters, places," in the climatology established by Hippocrates). ${ }^{9}$ Waters were animate; they had agencies that were described as "virtues" inherent to them. The science of chemistry reshaped this idea by isolating the efficacious chemical elements in the water that generated pathologies and therapies, and recasting the water itself as an inert medium. When, around 1880, the understanding of health moved toward the presence or absence of harmful microscopic organisms in the environment, the material agency of waters was reassigned to the organisms, further robbing the waters themselves of agency. Despite this, the view of water as an inanimate, uniform medium for biological agents never took complete hold. In fact, water culture in Mexico was remarkably conservative, retaining the ancient focus on the relation between bodies and local environments. Even while microbiology changed understandings of health and hygiene, doctors and laypeople continued to view mineral waters as important agents of well-being.

The shifting coexistence of medical scientific paradigms is exemplified in the work of two of Mexico's most important scientists in the nineteenth 
century: Leopoldo Río de la Loza (1807-1876) and Eduardo Liceaga (1839-1920). Leopoldo Río de la Loza was a chemist and professor at the National School of Medicine. Born into a family of chemists, his studies of chemistry and medicine in the university launched him on a successful career as an academic. At the same time, he founded a number of chemical factories and came to own three pharmacies, or boticas: "La Portacoeli," "La Botica de Vanegas," and "La Merced." Boticas often sold mineral waters and the salts that were derived from them as treatments, and some chemists and pharmacists replicated those in their laboratories. L. Pauer, for example, produced copies of mineral waters from Vichy, Spa, Carlsbad, and other famed European watering places in the Botica del Refugio, on Espiritu Santo street in downtown Mexico City. ${ }^{10}$

Río de la Loza was part of this process of the constitution of science far from Europe. He was instrumental in compiling the Farmacopea Mexicana (1846) and the Nueva Farmacopea Mexicana (1874), both with long sections of recipes for mineral and medicinal waters. He conducted numerous studies of waters during the mid- and late nineteenth century that were aimed at identifying the hygienic and therapeutic effects of waters in Mexico. In 1840 he published a study of the effects of lead pipes on water quality in Mexico City; in 1844 he was called upon to do an analysis of the waters of Peñón de los Baños and later published a study of the mineral waters of Atotonilco. ${ }^{11}$ In 1847 he was commissioned to study the Xacopinca spring; in 1858 and 1863 he published analyses of artesian wells. In 1869 he served on the Comisión Sobre las Aguas Potables de Mexico, and later published a study of springs and potable water in Teotihuacan. ${ }^{12} \mathrm{He}$ was a member of the Sanitation Board (Junta de Sanidad) of Mexico City, and later of the National Health Council (Consejo Superior de Salubridad), the independence-period heir to the colonial police of public health. ${ }^{13}$

Río de la Loza led the geological and chemical study of groundwater in mid-nineteenth-century Mexico. He quickly developed a close relationship with Sebastián Pane, describing his drill as the "exploratory probe" for his studies. In October 1858, at the beginning of the boom in artesian wells, Pane sank a well at \#2 Calle de Santa Catarina, northwest of the Zocalo. Río de la Loza and fellow chemist Ernesto Craveri studied the soils extracted by the drill, compared them to samples from other wells drilled at that time, and generated an image of the geological formations underlying Mexico City. "Because of this information," they wrote, "we believe that in this valley, at the depth of fifty meters more or less, there are three strata of water that have the conditions necessary for supplying artesian wells." ${ }^{14}$ They concluding that each of these aquifers held its own kind of water, hydrostatic pressure of these aquifers varied, and depending on their depth the artesian wells produced between 720 and 2,88o barrels of water each day. ${ }^{15}$ Río de la Loza's geological studies helped promote the assumption of opulence of groundwater, for while many at the time assumed that the water from the new artesian wells would run out, he declared with scientific certainty that the artesian wells were "permanent." ${ }^{\text {16 }}$ 
Another pressing question about artesian wells concerned public health and the chemical composition of the waters. Would they harm? Could they heal? When the first artesian wells in Mexico City bubbled forth, these strange new waters were not well received by the wealthy households they served. People claimed that the artesian water upset their stomachs and made their hair fall out. Some of the first wells produced salty water because the engineers did not prevent surface water from mixing with that drawn from deeper aquifers. City dwellers complained that water from some of the wells, such as those on the Calle de Los Cordobanes (today, Calle de las Donceles) and the Aduana (today, Calle 5 de Febrero), was "azufrosa" (sulfurous) or "hedionda" (stinky), because of a sulfurous smell that reminded them of hot springs. ${ }^{17}$

Río de la Loza and Craveri were commissioned by Pane and the Chamber of Industry of Mexico City to determine the healthfulness of artesian waters and compare them to others in the Valley of Mexico. Like the mass of people without scientific training-often referred to by scientists as the "vulgo"-scientists in 1850 began with the assumption of miasmatic theory that foul smells in air or water were bad for health, and understood these miasmas in terms of chemistry and climate, not microbes or bacteria. ${ }^{18}$ The artesian wellwater smelled badly, and Río de la Loza sought to identify the minerals that caused the smell and to understand their effects on the "economy" of the body.

Río de la Loza concluded that the artesian waters were better for the health of the public than others in the Valley. The sulfurous smell that people noted was actually a harmless gaseous hydrocarbon that would lessen over the life of the well, and would evaporate from the water if left standing. Popular ideas that groundwater caused people's hair to fall out were simply unscientific and wrong. "When some inhabitants of Mexico City," he wrote in 1863, "who are used to drinking the socalled 'thin' water [agua delgada], change it for the 'thick' [agua gorda], their digestion will suffer for a few days, more or less." ${ }^{19}$ His analysis showed that the "thick water" had more dissolved minerals than groundwater, and argued that it was the calcium and magnesium, as well as the salts, that caused these digestive problems. But, he argued, the artesian wells produced clean water with relatively little dissolved minerals. Artesian water, Río de la Loza insisted, was not bad for people, and to protect public health hygienists should instead take aim at social and cultural factors such as "habits, changes in location and dwelling, etc." ${ }^{20}$ Río de la Loza recommended using water from the third aquifer from the surface, which was of better quality than the first water-bearing strata that was cheaper to access. ${ }^{21}$

Río de la Loza was at the forefront of medicine and public health in Mexico in the mid-nineteenth century. He lived to see John Snow's discovery in 1854 that cholera and other diseases were transmitted through London's groundwater, and that it was germs rather than miasmatic gases and airs that caused disease. But he died in 1876, just two years before Pasteur published his landmark study Les Microbes Organisés, which sparked a hot debate at the 1878 Hygiene Congress in Mexico City between the established medical tradition and the new adherents to 
microbiology. Río de la Loza left the National School of Medicine solidly oriented toward chemical analysis, but in the following decades medicine and public health would slowly incorporate biology.

This transition can be seen in the life and work of Río de la Loza's most notable student, Eduardo Liceaga. Liceaga passed his medical exam in 1866, and went on to be a leader in science, health, and medicine in Mexico until the twentieth century. In 1887 and 1888 he toured the capitals of Europe, visiting hospitals and the Pasteur Institute in France, and returned to Mexico with materials for vaccinations against rabies and, having visited sewer and potable water systems, a keen interest in public works, hygiene, and water. He adopted the bacteriological approach and created modern institutions that characterized health in the twentieth century, serving twice as president of the National Academy of Medicine. He was an important political figure who also held the presidency of the National Health Council, helped write the 1891 Sanitary Code, oversaw the construction of the National General Hospital (1905), led the prophylactic effort to identify and quarantine yellow fever in Mexico's port cities, and founded Mexico's National Bacteriological Institute in 1905. As the personal doctor of President Porfirio Díaz, who ruled during most of the period between 1876 and 1910, his access to power was guaranteed.

Despite Liceaga's remarkable success in promoting microbiological approaches to health, there was no moment in the history of medicine in Mexico that marked an abrupt break from earlier approaches to health that focused on climate and environment. As Eric Jennings (2006) has shown in his study of hot springs in France and its colonies, the turn away from climatology was a slow process of incremental change as centuries-old views of health bent, adapted, but only sometimes broke under the force of the new paradigm of microbiology. According to Paul Ross (2009), doctors in Porfirian Mexico continued to "explain disease as a complex relationship between local environmental conditions (especially miasmas) and individual predisposition," rather than a result of tiny organisms. ${ }^{22}$ So while Liceaga ushered in the bacteriological approach to health in Mexico, he was also a leading proponent of therapeutic bathing and mineral waters.

Water continued to be a principal concern of doctors and health officials in Mexico City. The proliferation of artesian wells in the 1850 s and 1860 os focused attention on the quality of groundwater at a time when scientists were still mostly focused on chemical virtues. The huge increase in water supply generated by these artesian wells only accentuated the problem of stagnant and noxious waters, which formed wetlands around uncapped wells and sluggish pools in the city's drainage canals. By the 188 os the stench of nearby Lake Texcoco, which received the city's effluent, was unbearable to many among the educated elite who, informed by discussions of hygiene, sought to create a more sanitary city.

In 1882, the National Academy of Medicine commissioned a study of "the influence of waters for domestic use on the public health of the Capital." The result, Antonio Peñafiel's Memoria de las Aguas Potables de la Capital de Mexico, shows the evolving balance between chemistry and biology, and climate and microorganisms, 
in ideas about waters, health, and cleanliness. In that document, chemical analysis was still paramount, but following the emergent emphasis on microbiology the object of study had turned to the putrefaction of organic material in the water, caused by the explosive growth of microscopic plants and animals "in the millions." ${ }^{23}$ Air, water, and organic material were the key ingredients for this fermentation, a process which consumes oxygen and produces carbonic acid and ammonia. Peñafiel followed the work of Pasteur, but his analysis of water and health pointed him back to the chemistry of waters-to the presence of carbonic acid and ammonia as identifiable markers of infection in the waters of the Valley of Mexico. "Pasteur has not finished building his theory, but we can seize on the most prominent and visible results of these vital, chemical actions," Peñafiel suggested. ${ }^{24} \mathrm{He}$ offered a discussion of microscopic analysis of bacteria in water, but in practice gauged the relative chemical purity of waters in the Valley of Mexico by the presence or absence of macroscopic living organisms such as fish and snails. The microbiology of contagion was still something of a black box in Peñafiel's climatological method and theory.

While climatological perspectives may have held their own in discussions of potable water between 1880 and 1920, they actually grew in prominence overall due to their role in the dramatic growth of the business of bathing. Water was neither just the medium through which microbiological threats to public health came into contact with people, nor the substance that could be used to wash those threats away. Waters themselves were increasingly considered crucial for both hygiene and therapy among doctors and the public, despite the emergence of homogeneous public water. This resurgence of the conceptual specificity and multiplicity of waters, and of the notion that waters were agents in a climatologically informed health system, unfolded in the practices and places of the bath.

\section{BATHING FOR HEALTH: THERAPY AND HYGIENE}

"There is nothing like water; it will cure all complaints but poverty, and heal all wounds but sorrow! Do you find yourself afflicted in mind, melancholy, or disposed not to hear mass? Drink water, and bathe yourself in the river. Are you stung by a scorpion? Bathe the wound in water: and for the bite of a rattlesnake it is equally efficacious. I am sixty-nine years of age, and for 35 of these I have been a water carrier; and during the whole of that time I have preserved my health by drinking water! There is nothing like water for the head or toothache. Warm water however swells the stomach; but cold water, that is the thing-used three times, it is a remedy for soul and body: for coughs, colds, rheums, colic, and in short every other complaint whatsoever, a liquor for angels to drink with pleasure and advantage."

-Water carrier, Lagos de Moreno, Jalisco, 1829

Source: Hardy 1829: 497. 
During the Porfiriato, artesian groundwater and the idea of hydraulic opulence encouraged the massification of bathing for cleanliness as well as social and ludic ends, but many people continued to treat maladies with water. As we have seen, the quality of the particular water was often seen to be the curing agent, and water cures employed the entire range of waters, from pure, fresh springwaters to the most heavily mineralized hot springs, as well as seawater. ${ }^{25}$ Each of these waters was thought to have particular properties that made it useful for treating certain diseases. Hot springs were especially important, and the study of hot springs in the late eighteenth century and nineteenth centuries was focused on generating classifications for the mineral contents of those springs and their utility in treating different conditions. The physical action of water on the body was also thought to have therapeutic effects, and a plethora of showers, baths, and drinking schedules were designed to apply water to different parts of the body. For these applications, the content of the water was not as important, and the showers, baths, and other applications utilized whatever water source was at hand.

Therapeutic bathing was practiced in different forms by ordinary folks across Mexico. In the 1820 medical doctor Robert Hardy toured northern and western Mexico, and reported with ethnographic detail on regionally specific popular customs and ideas about water. Hot springs were considered by people in northern Mexico to be curative, but bathing in cold waters was not. ${ }^{26}$ In Sonora, snakebites were washed with cold water, while immersion was seen to be harmful for people with colds. Those with smallpox and measles stopped washing altogether for forty days. When Hardy ordered a bath for a sick young girl, her father swore that "he had not closed his eyes during the whole night, as he thought it was not possible that his daughter should survive the washing. ${ }^{27}$ The doctor remarked that in this region there was "a kind of superstitious awe felt by the natives in regard to ablutions. ${ }^{28}$ On the other hand, in Lagos de Moreno, Jalisco, water was promoted as something of a cure-all, at least by a man selling the water. This same strong idea of the beneficial virtues of water was observed fifteen years later in Lagos by Albert Gilliam, who wrote that the patient "was directed first to bathe seven times, and that afterwards [the doctor] gave him some roots, of which he made teas to drink." ${ }^{29}$ Like Hardy, Gilliam considered this to be "superstition" rather than science.

Popular water cures were influenced by transnational trends in medicinal water culture, as was the idea held by others that these cures were unscientific. The "hydropathy" of Vincent Priessnitz was especially influential. Priessnitz was an Austrian with no medical training who established a treatment center on his farm in 1826 . He practiced a regime of coldwater showers and wraps, together with a diet of simple regional food, which by 1840 had become famous enough to attract visitors from all ranks of society, and from as far away as England and the United States..$^{30}$ Soon hydropathic treatment centers were popping up around Europe and the Americas. Alistair Durie shows how these "hydros," with their 
abstemious and ascetic qualities, gained adherents among a middle class that turned away from the perceived decadence of spas. ${ }^{31}$

Hydropathy also gathered followers in Mexico during the 1840 os and 1850 . But in addition to the idea that it was a more respectable water cure than the spa, Mexican proponents of hydropathy argued it was more popular and democratic. The hydropathic regimen utilized cold, pure water flowing directly from the source for bathing and drinking. ${ }^{32}$ According to this perspective, pharmaceuticals were damaging; no other substance than cold pure water was medicinal, not even mineral water. ${ }^{33}$ In Europe at that time, public access to hot springs was increasingly restricted by the doctors who made their business with them. Hydropathy encouraged people to make their own cure, as cold water, unlike hot or mineral water, was universally available. In the 1840 s hydropathy enjoyed a wave of popularity in Guanajuato, Guadalajara, Silao, Morelia, and Mexico City, promoted by Emeterio Sáez de Heredia and José Nogueras, both priests from overseas. ${ }^{34}$ It became so popular in Guadalajara that 150 citizens petitioned the city government to formally endorse the treatment. ${ }^{35}$

Hydropathy was fiercely debated and hydropaths were pitted against the scientific medical industry. Emeterio Sáez explicitly avoided scientific language in an effort to "be understood by the poor and ignorant." ${ }^{36}$ Instead, he presented his water cure in religious terms reminiscent of studies of mineral springs from the eighteenth century in Spain and Mexico. ${ }^{37}$ While popular notions of health were still rooted in this language, by the mid-nineteenth century it had been purged from scientific discourse, a turn strengthened further by growing Liberal anticlericalism during the late 1840 and 1850 s. Sáez attacked scientific medicine, fulminating against the "ambition of glory and fortune" that motivated doctors. He argued that the medical profession attacked hydropathy because it "robbed them of their science ... the pharmacist trembles, fearing for his business and his drugs." ${ }^{8}$ José Nogueras, also a priest, echoed this therapeutic populism when he told his readers "do not expect the flowery language of the classroom, nor the elegant style common in prologues: I will speak to everybody, following the path of nature." 39

Medical doctors rejected hydropathy as a "vulgar," empirical approach that lacked scientific theory of disease and knowledge of anatomy, and they labeled its proponents "charlatans." ${ }^{\circ}$ At the behest of doctor Juan Manuel González Urueña, José Nogueras was ordered by the government of the City of Mexico to stop practicing hydropathy, although Nogueras later got the federal government to lift the ban. While most doctors in Mexico looked upon those who practiced hydropathy to be quacks, they were at the same time careful to recognize "hydrotherapy," or the scientific use of water in medicine, as legitimate. ${ }^{41}$ At stake was the conceptual and practical system by which water was applied to medical ends, not the status of water as a useful substance for medicine. As a result of the hydropathy episode, however, Mexican doctors turned away from water treatments until the 1870s, when the Military Hospital, the Hospital de San Lucas, and some of the 


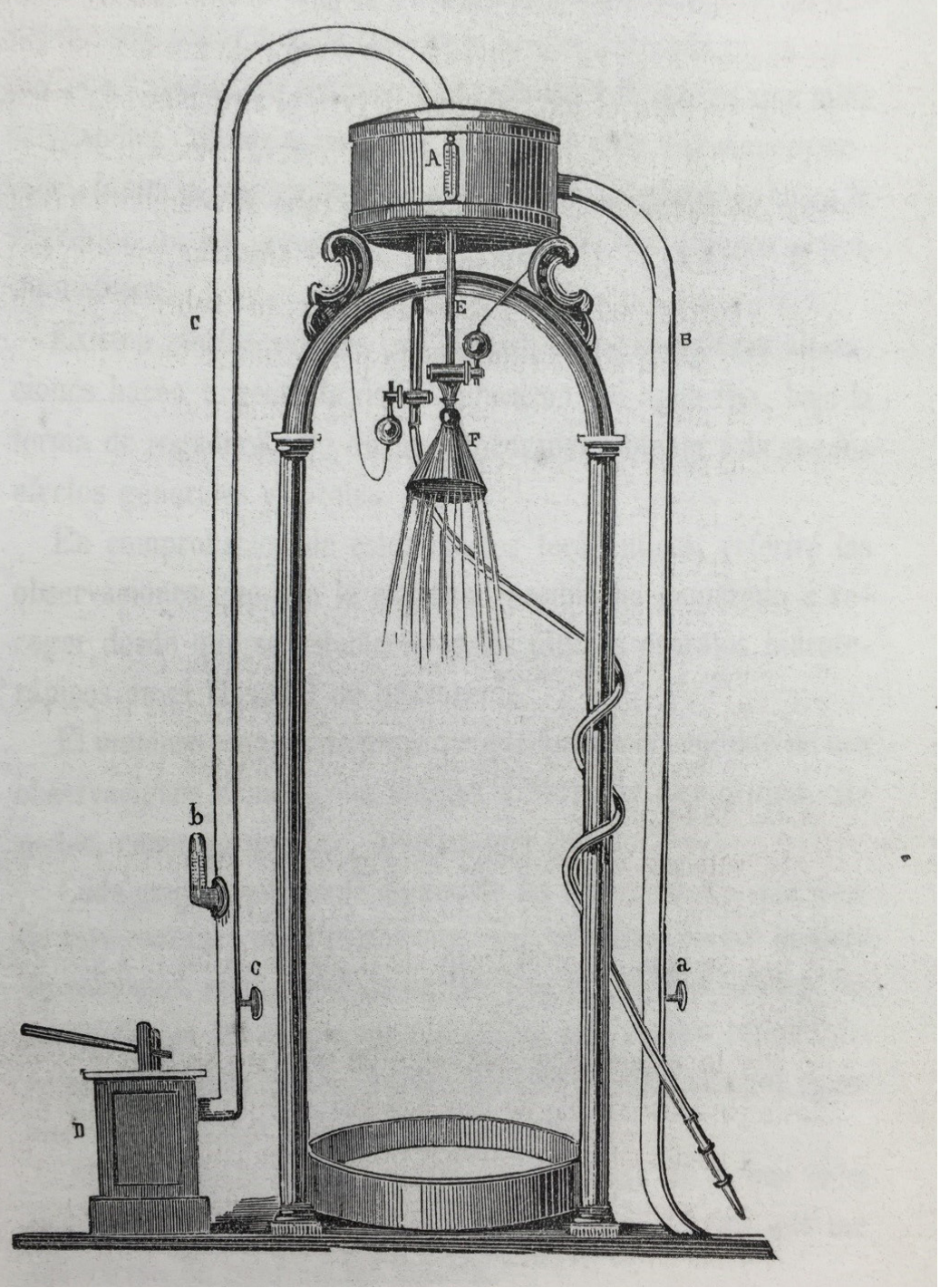

FIGURE 8. “Shower, Fleury Design." Lugo 1875: 17.

Mexico City bathhouses installed showers modeled on Louis Fleury's equipment in his baths at Bellevue-chez-Meudon, France. ${ }^{42}$ Therapeutic bathing was further institutionalized in the National School of Medicine, where numerous theses were produced on the topic between 1875 and 1910. All of these hydrotherapeutic showering and bathing facilities utilized the waters of the public water system, irrespective of their origin in the Chapultepec springs, the springs of the Desierto de los 
Leónes, the new pozos artesianos, or the Xochimilco springs. In these versions of hydrotherapy it was the physical force of the water, more than its mineral content, that was considered curative.

Interest in the therapeutic qualities of mineral springs never died. The medical history of mineral waters in Mexico has been ignored by historians who focus instead on the botanical elements of medicine, but we know that scientists and doctors did work on these extraordinary waters. ${ }^{43}$ The Royal Botanical Expedition to Mexico in the 1790 s carried out studies of the waters of Cuincho and San Bartolomé, and Jardín Botánico director Vicente Cervantes extracted the minerals from them by evaporation. ${ }^{44}$ In 1795 Antonio De la Cal y Bracho, who took Cervantes's 1792 course on botánica and became the correspondent in Puebla for the Real Expedición, carried out an identical study of the mineral waters and local plants of Tehuacán. ${ }^{45}$ Although he did not further explore the place of the "reino mineral" in Mexico's national popular-medicine tradition, focusing instead on botánica, he clearly defined the need for further studies of mineral springs. ${ }^{46}$

In 1850 most hot springs in Mexico were rustic and undeveloped, and the bathhouses that did exist dated to the colonial era. Regardless, people in Mexico continued to utilize hot springs for bathing, drinking, and even inhaling cures. In 1844 Ernesto Masson lambasted the 1790 remodel of Peñón, saying that "everything about the place reveals the poor taste of the era." 47 But this was also his dismissal of the everyday folks who kept the baths "in vogue" throughout the years, and their "vulgar" ideas about the medicinal properties of the waters. The humble used the bathhouse, and the very poor simply took half-baths sitting in the drainage canal outside of the bathhouse. ${ }^{48}$ Masson notes that while the Mexican elite was developing an interest in scientific therapeutic bathing, this did not result in improvements in Peñón and greater use of the waters. The rebuilding of Peñón may have been frustrated by the inheritance dispute discussed in chapter 3 , but elites did not travel, as their European counterparts did massively throughout the nineteenth century, to any other hot springs until around 1890 , when hot springs bathhouses were built in Aguascalientes, Tehuacán, and Topo Chico.

Those who sought out and wrote about Mexican mineral springs were often foreigners who had experience with European health spas. In 1835 Francesco Antomarchi, Napoléon Bonaparte's last doctor in Corsica, lived for a brief period in Mexico and visited a number of hot springs: Xochitepec (Morelos), Atotonilco de Santa Cruz (Zacatecas), Ojocaliente (San Luis Potosí), and "Agua de San Ramón" (Aguascalientes). Antomarchi, who would die in Santiago, Cuba, in 1838, was ill at that time, and it is likely that he was searching for a cure. Just a day's travel south of Mexico City, the Atotonilco springs were hemmed by a masonry wall that formed a pool where men and women bathed together. In Ojocaliente there were two well-kept bathhouses attached to the pool, one for each sex. Antomarchi conducted the customary analysis of the waters of each-temperature, chemical content-and derived a determination of their usefulness for treating different 
medical conditions. ${ }^{49}$ Regino Gayuca, who transcribed this report in 1843 for the journal of the National Museum of Mexico, wondered why "if in many parts of Europe they value thermal waters and have identified their minerals, we hardly mention those that we have in this America?"50 Aguascalientes had been known for its curative hot springs since its foundation in the sixteenth century, and Antomarchi, together with a group of local intellectuals, conducted an analysis of the waters of the San Ramón springs. ${ }^{51}$ None of these springs attracted the interest of cosmopolitan urbanites, and none were developed into bathing establishments until the 188 os.

Any mention of hot springs by proponents of therapeutic bathing was inevitably followed by dejected comparisons to the advanced state of installations and practices elsewhere. In 1840 Francis Erskine (Fanny) Calderón de Vaca visited Peñón de los Baños, told of its decrepit state, and offered a vision of the thriving business that could be built at the site by an "enterprising Yankee." Between 1844 and 1849 Ernesto Masson, a naturalized French immigrant, carried on a heated debate in Mexico City's press with the goal of improving the state of the Peñon baths, which was mired in an inheritance dispute, so that patients could make use of its "astonishing virtues." ${ }_{52}$ He lobbied the city government to expropriate Peñón and sell it to Anselmo Zurutuza, who promised to build "a European-style thermal bathhouse." 53 Ramón Malo, governor of the Distrito Federal (DF), ordered the National Health Council to study Peñón and identify its medical benefits, in the model of countless other hot springs studies, and Leopoldo Río de la Loza and Ernesto Craveri published their report in 1849. By then, however, the DF had a new governor, Pedro Jorrín, who did not care enough about Peñón de los Baños to proceed further. In 1858 a similar study was carried out in the mineral springs of Tehuacán, ${ }^{54}$ and Peñón's waters were analyzed again a few decades later in Paris, ${ }^{55}$ but the springs and their ancient bathhouses did not receive investment by developers.

Mexico's pharmacists, however, did make a business of mineral waters. Whereas the 1846 Farmacopea Mexicana included water as a medium for preparing herbal infusions (agua de azahar, agua de canela, agua de hinojo, etc.), the Nueva Farmacopea Mexicana published in 1874 included an appendix on "Waters" with chapters on potable waters, natural mineral waters, and artificial mineral waters, the last with recipes for the contents of famous European mineral springs. Included in this appendix are chemical analyses by Río de la Loza of various Mexican hot springs, as well as by Baguerisse and Lambert. Mineral waters had become part of Mexican modernizing medicine, and Mexican doctors and pharmacists were influenced by the growing role of hot mineral waters in European medicine. For example, Plácido Díaz's 1876 study of the hot springs in Puebla pointed to their usefulness in treating tuberculosis, an analysis that built on the European tradition of treating that disease with fresh air and mineral springs. ${ }^{56}$ In 1878 the Mexican National Academy of Medicine announced a competition to study Mexico's mineral water, indicating the resurgence of mineral waters in medicine at the time. 
José Lobato won the contest with a comparative analysis of the springs in Villa de Guadalupe and Peñón de los Baños. ${ }^{57}$ The competition was one of two about water that were announced in 1874: Antonio Peñafiel won the other with his treatise on potable waters. ${ }^{58}$

Lobato announced the victory of scientific medicine over "vulgar," "empirical" traditions of hydrotherapy, writing that "little by little the belief in the therapeutic effects of mineral waters has turned into a scientific doctrine, and that this has become known to all social classes in the civilized countries of Europe, America, Asia, etc." ${ }^{59}$ Lobato's analysis and classification of the mineral waters was based in European models, but he adjusted them to grapple with the specificities of the mineral waters in Mexico. In doing this Lobato built upon the tradition of studying the chemical and mineral qualities of water that was developed by Río de la Loza. He privileged the geological origins of the waters in his classification, complementing the therapeutic orderings proposed by French scholars and doctors Etienne Ossian Henry, Maxime Durand-Fardel, and Jules Lefort. Lobato established seven families, fourteen classes, fifty-seven genders, and a scattering of species of mineral waters in his system, all according to their chemical composition and geological origins. ${ }^{60}$ The therapeutic agency of a water, described in the eighteenth century as its "virtue," was recast as a "medicinal, mineralogical principle that gives expression to a medical power." ${ }^{11}$ This science did not rid waters of their efficacy.

\section{STRUGGLING TOWARD SPAS}

In the 1870 , mineral springs in the Valley of Mexico were converted into bathhouses, part of the wider profusion of bathing at the time. The hot springs bathhouse of Peñón de los Baños languished in a rudimentary state, but bathhouses were built at two sources of ferruginous (iron-bearing; also known as "chalybeate") waters to the north of the historic center. The spring at Aragón was located on the side of the road leading into the religious center of Guadalupe. The owner of the land was prompted by the rising popularity of bathing in the 1870 s to unearth the spring, which until then had been considered a nuisance. He commissioned an analysis of the waters by the chemist Gumersindo Mendoza, and built a bathhouse in 1875 with a few placeres in small private rooms, a garden, and a ten-by-tenmeter swimming pool. ${ }^{62}$ Soon a steady stream of patients treated anemia and other maladies with the iron-rich waters. The other mineral water baths near Guadalupe were named the "La Estación," and were located a few steps from the station of the train that brought visitors from Mexico. Eduardo Liceaga built that bathhouse in 1878 , supplying it with an artesian well perforated by the Beléndez and Velázquez company. It had six "first class" rooms with placeres, a bottling room, a gynecological treatment room, a room of showers, a garden and more, and was designed in the neoclassical style of a Pompeian villa similar to that of the bathhouse in the Bosque de Chapultepec. 


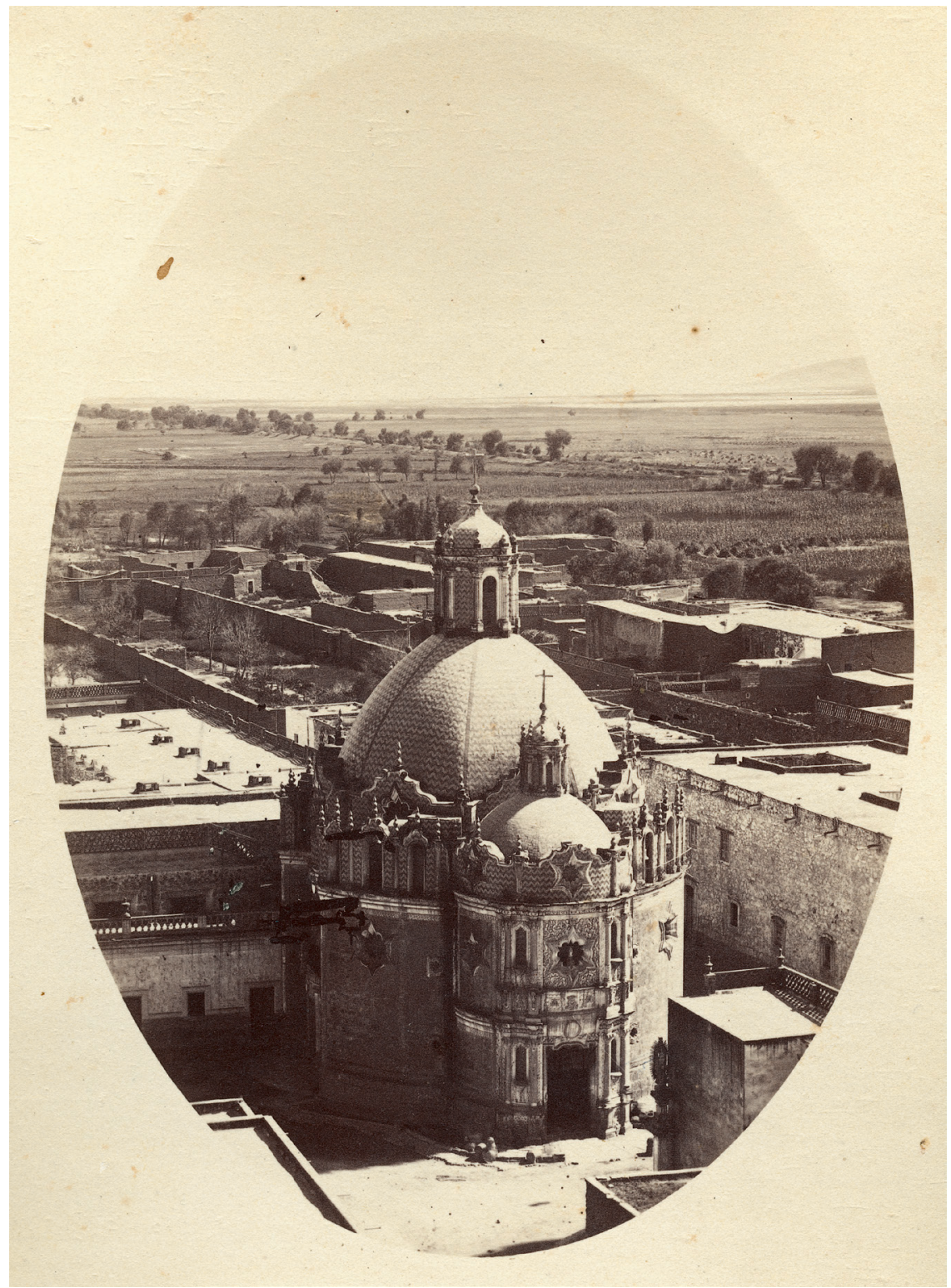

FIGURE 9. El Pocito, Villa de Guadalupe. Michaud 1874. With permission of Universidad Nacional Autónoma de México, Instituto de Investigaciones Estéticas, Archivo Fotográfico Manuel Toussaint, Colección Julio Michaud. 
These bathhouses were built with clear scientific medical justifications. Nevertheless, they both served a clientele that was drawn to Guadalupe by the religious fame of the mineral waters of the nearby Pocito, a spring that became a Christian holy site in the sixteenth century and was considered to mark the site of the appearance in 1531 of the Virgin de Guadalupe to Juan Diego. People considered the waters to be "miraculous" and curative, and the crowds that came to drink and bathe were so great that the church erected a structure around the spring in 1648, and in the 1770 s built a baroque chapel (see figures 9 and 24). The spring welled up in a twometer receptacle inside the chapel, with a grate on it that prevented people from climbing in to bathe. A copper cup on a chain was attached to the grate so that pilgrims could drink the waters. Río de la Loza analyzed the waters of the Pocito and argued that they were more effective than similar springs in Europe, and far better than the patent medicines being produced at the time. ${ }^{63} \mathrm{He}$ found the waters of La Estación and Aragón to be similar but not identical in their mineral composition.

Lobato judged most Mexican bathhouses woefully underdeveloped in comparison to the spas of Europe. He decried the failure to institute medical hydrotherapy in terms of science and tradition, but was aware that this had a lot to do with social class. A major obstacle to the development of modern bourgeois bathing was the "routine of tradition" that governed the therapeutic use of these waters. Most bathhouses served humble clients who had, for centuries, made the pilgrimage to Guadalupe for the miraculous properties of the waters, but who could not afford, nor were interested in, expensive and lavish facilities. Bathhouses, Lobato argued, should be run by doctors and trained managers, much like textile factories should be run by directors and mechanics. ${ }^{64}$ These doctors and managers should be schooled in the latest science in order to deal with the complexity of the mineral content and temperatures of the waters and their application to a variety of maladies through a variety of systems: tubs, showers, inhalation devices, etc. Empiricism and routine - the heart of popular medical traditions-prevented the implementation of more sophisticated and effective mineral water therapies.

Both business and government needed to intervene, Lobato argued. The two bathhouses in Guadalupe were attracting visitors from Mexico City, but neither was adequately capitalized, and hotels, guesthouses, doctors' offices, restaurants, and other amenities common to the European spa towns such as Vichy were completely lacking. While the business of bathing might not be rewarding, baths were also a service offered to the public, and the meagerness of profits should not deter Mexican investors from building first-rate spas where scientific medicine could flourish. Government needed to help as well. Mexico City's Distrito Federal had no medical inspector to oversee hydrotherapy treatments; there were no doctors attending to the sick at the bathhouses. The Consejo de Salubridad, Lobato argued, needed to treat mineral waters as a public health issue. "In our country," he stated, "we still today have no knowledge of the regulations of sanitary police that are required for bathing establishments of this kind." 65 


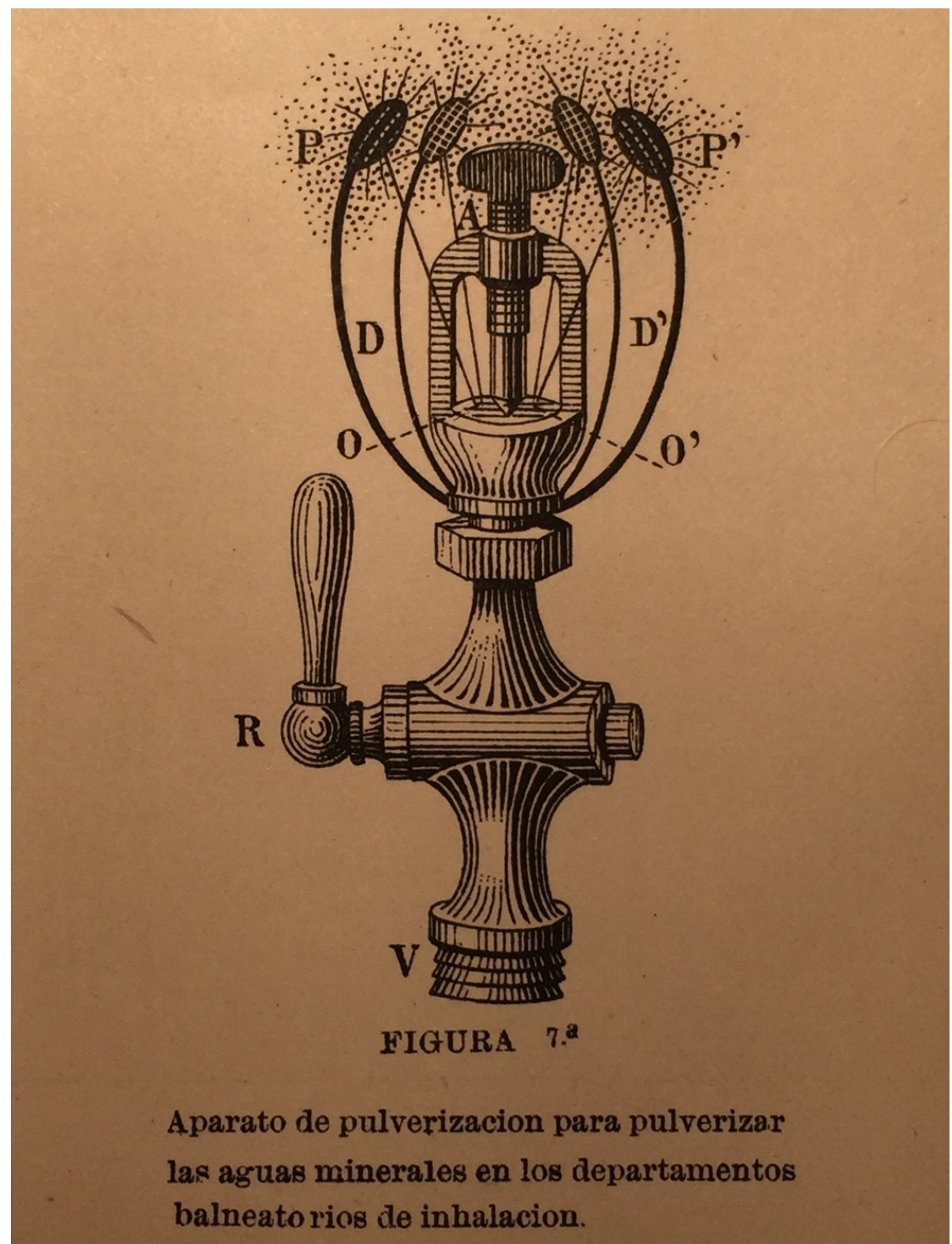

FIGURE 10. "Misting apparatus for pulverizing mineral waters in the inhalation departments of the baths." Lobato 1884: insert between pp. 192 and 193.

While in the late eighteenth century the ruling class policed the sexuality and sociality of plebian bathing, for Lobato policing was needed primarily to counteract the weight of popular medical traditions: empiricism, folk knowledge, religious beliefs. "Take a look at the buildings in Aragón and Guadalupe, on the one hand, 
and Peñon, on the other, and you will see that they are none other than common baths, fitting for a population that has little civilization, scientifically and socially speaking." ${ }^{66}$ There was the lack of mass appeal for bourgeois scientific bathing practices and bathhouses, and crowds still administered their own treatments at Peñon, despite its decrepit state, because of the widely held idea that they were useful for treating rheumatism and infertility among women. Lobato dismissed the plebeian bathing tradition as superstitious "empiricism" that eroded the prestige of those hot springs among scientists. The mass appeal of the Pocito de Guadalupe was due, he argued, to the fact that "the Spaniards made indigenous converts believe that the spring is miraculous and supernatural." ${ }^{67}$ So strong was the belief in the holy, curative powers of the waters that faithful craftsmen and even elite matriarchs donated their Sundays to building the chapel in the 1770 - no labor was hired. ${ }^{68}$ And this was the root of the issue: the reforming mineral water doctor was promoting a water culture that was not shared by almost anybody else in Mexico.

"Mexican mineral hydrotherapy is destined to figure notably in the annals of science."

—José Lobato, 1884

Source: Lobato 1884: ix.

Porfirian scientists often complained about a lack of basic science concerning mineral waters, but by 1886 there were already analyses of 116 different Mexican mineral springs. ${ }^{69}$ The same impression of paucity was shared by French colleague Emile Delacroix, whose 1876 study of the world's mineral waters mentioned Peñon and Guadalupe, but found that the curative properties of their waters were yet to be properly classified. ${ }^{\circ}$ Clearly there were long-standing traditions of taking the waters among everyday Mexicans, but in the early 188os Mexico did not have a robust enough bourgeoisie with modern Europeanized concepts of health, medicine, and leisure to support investment in mineral water spa establishments such as those in France and Germany. As Friedrich Semeleder, former doctor to Emperor Maximiliano and Empress Carlota and a member of the Mexican Academy of Medicine, put it, "in Mexico there is not the same kind of mania for mineral waters that there is in Europe." ${ }^{71}$

Some doctors and politicians rejected the Eurocentrism of spa medicine, framing their project instead in terms of the specificity of Mexican bodies and environments, a nationalist, climatological strain of thought with precursors in the late eighteenth century. In 1886 the National Academy of Medicine, "mortified" by the idea that Europeans would hold more interest in their hot springs then they did, approved a national-level study of Mexico's mineral waters with the purpose of 
generating scientific information to support medical applications and the development of spas. ${ }^{72}$ In 1889, Carlos Pacheco, Minister of Development, created the National Institute of Medicine (NIM), with the mandate to "possess truths discovered in this country, and perhaps in some cases only applicable to this country."73 At the same time a major survey was conducted by the Ministry of Development to collect climatological information from the 2,863 municipalities of Mexico, an interest that was shared by Liceaga. ${ }^{74}$

"If, because of our climate, geography, race and customs we have a different phys-
iology, idiosyncrasy, morbid receptivity, and constitution; if our fauna, our flora
and our waters are not the fauna, flora and waters of other places: why, then, if
we have such varied national elements, have we not created a national science?"
- Secundino Sosa, 1889

Source: Sosa 1889a: 2.

Pacheco believed in the therapeutic efficacy of water. He was a regular visitor to the Alberca Pane, where he swam in the pool and used the baths. ${ }^{75}$ Hydrotherapy was a central focus of climatological models of health, ${ }^{76}$ and Pacheco had a special interest in developing both the science and business of mineral springs, which were, in the words of Secundino Sosa, director and founder of the NIM's journal El Estudio, "almost completely abandoned." "7 Over the next two decades the NIM conducted an ongoing effort to study the country's waters and "form a hydrological repertoire with chemical and therapeutic uses." ${ }^{38}$ Whereas Lobato called on government and business to develop Mexico's mineral waters into spas, Sosa argued that it was the doctors who had to bring together the science of hydrotherapy, the capital needed to build spas, and the clients to keep those spas functioning.

Eduardo Liceaga was the kind of doctor that Sosa was interested in; one who promoted the science as well as the business of bathing in Mexico. He was keenly interested in the role of water in public health, and pushed therapeutic bathing with the same conviction that he promoted modern water supply systems and sewers. Liceaga was born in Guanajuato in 1839 into a family of doctors, and graduated from the National School of Medicine with honors in 1866; Leopoldo Río de la Loza was a member of his exam committee. He was at the center of the worldwide turn to microbiology, visiting the Pasteur laboratory in the 188 os and returning to Mexico with plans for inoculations against rabies. He served as president of the Consejo Superior de Salubridad and director of the National School of Medicine and used these positions to elaborate building and sanitation codes for Mexico City. He also served twice as president of Mexico's National Medical Association and oversaw the construction of the General Hospital. ${ }^{79}$ Liceaga collaborated with 
Roberto Gayol, a hydraulic engineer who served as assistant director of public works for the Mexico City government and sat on the Consejo de Salubridad Pública. Together they designed and built the General Hospital, as well as the city's drainage system. The General Hospital, initiated in 1896 and concluded in 1905, was equipped with a hydrotherapy building that offered a variety of medicinal, therapeutic, and hygienic encounters with water. ${ }^{80}$ There was a swimming pool, Russian baths, Turkish baths, all kinds of showers, nozzles and sprayers for therapeutic applications, and cold and warm showers for personal cleanliness modeled after those used by the French military. ${ }^{{ }^{1}}$ The complex was supplied by artesian wells as well as city water and had a robust sewer system.

“That was precisely what [the girls'] mother and Dr. Liceaga sought. By enhancing the body's circulation, hydrotherapy bestows on the nervous system-which is so delicate, so exquisite, and so obedient-a far from negligible amount of what can be called the joy of living. .."

$$
\text { —José de Cuéllar, } 1941
$$

Source: De Cuéllar 1941: 23-24.

Doctor Liceaga was also deeply involved in the business of therapeutic bathing. He built "La Estación" bathhouse in 1878 and in 1880 published a study of the different springwaters of the Villa de Guadalupe. ${ }^{82}$ A decade later he turned his attention to a study of the mineral waters of Peñón, commissioned by Manuel Romero Rubio, secretary of Gobernación and father-in-law of Porfirio Díaz. ${ }^{{ }_{3}}$ Between 1887 and 1892 Romero built a sumptuous, modern spa at Peñón and Liceaga's study was, like all studies of mineral waters, both science and promotion. Liceaga presented it to the Mexican National Academy of Medicine, and immediately had it translated for distribution at the 1892 meeting of the American Public Health Association that he organized in Mexico City. ${ }^{84}$ Doctor Friedrich Semeleder described the study as "advantageous even from a financial point of view." ${ }^{85}$

The new Peñón bathhouse was as close to a European spa that could be found in Mexico. The bathhouse itself had two floors, the lower floor with a bathing area for men, decorated in Egyptian motifs, and one for women in an Aztec style. This mix of decorative elements from Old World and New World civilizations evoked the classical, Mediterranean roots of bathing in Mexico, participated in the Egypt-mania of the time, and by claiming a classical tradition of bathing was an assertion of Mexico's place among the world's civilized countries. ${ }^{86}$ The bathing apartments each had a bathtub room and another room where guests could recline on a bed and sweat. There was a room of showers, a sauna, and fountains of the mineral water for drinking. On the upper floors there were sumptuously furnished 


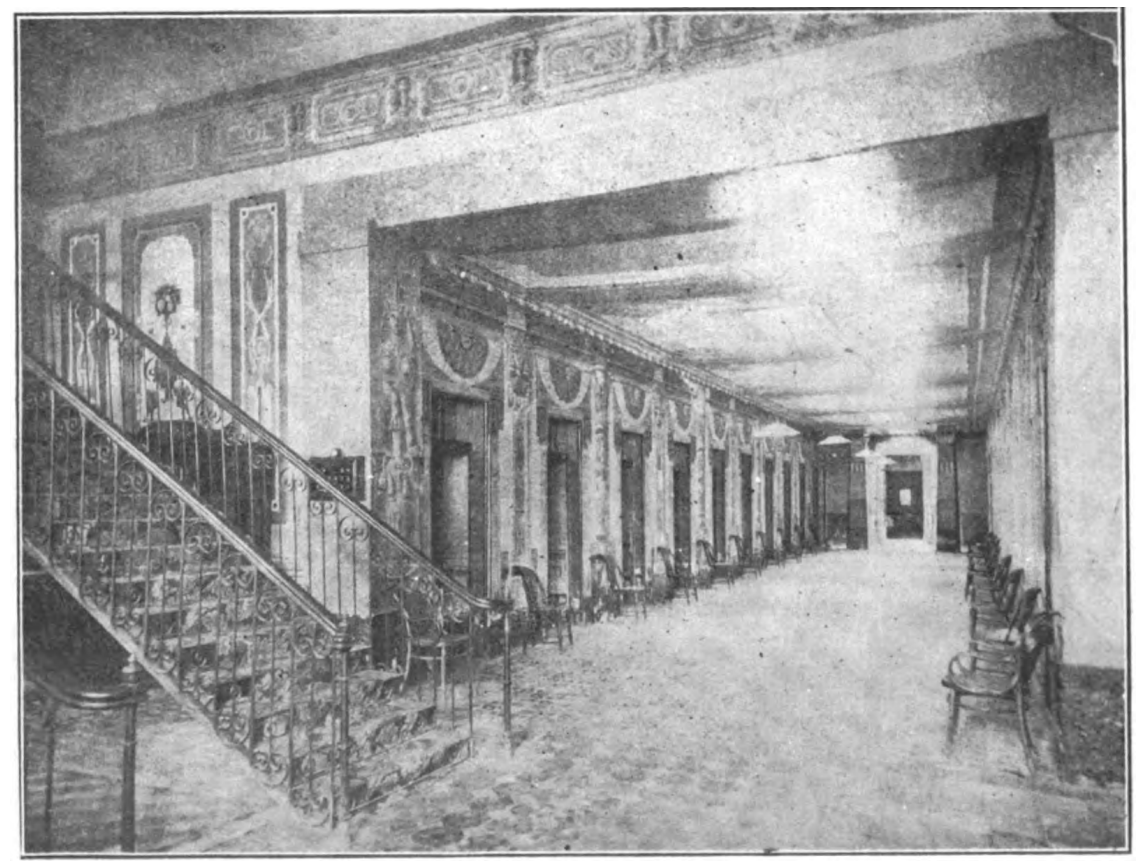

FIGURE 11. Departamento de Baños, Peñón de los Baños bathhouse. El Mundo Ilustrado 2, no. 12 (1906). With permission of Universidad Nacional Autónoma de México, Hemeroteca Nacional de México, Fondo Reservado.

bedrooms and meeting rooms, and nearby buildings held a chapel, a manager's quarters, a billiard saloon, a restaurant, and a bowling alley. The building offered "the most beautiful views of the Valley of Mexico" to aid the rest and recuperation of the clients. ${ }^{87}$ President Díaz himself reserved a special suite of rooms for his family at the spa. ${ }^{88}$

The new bathhouse was directed primarily at the Porfirian bourgeoisie. Different "classes and prices" of baths were available, allowing some of the humble folks who had used the waters before the bathhouse was built to continue to do so, but poor people no longer had access to the used waters in the exit channel. Liceaga provided the bourgeois clients with a guide to the rules of behavior at modern spas, so that the curing properties of the waters were complemented by diet, hygiene, rest, diversion, and leisure. Patients were advised to "change their habits entirely," to leave the stuffy houses and offices behind along with all the excitement and worries of business, rich food, late nights, alcohol, and "theaters and balls" that the bourgeoisie was accustomed to. He warned that treatment required prolonged stays, repeated over many years, and gave more precise instructions about bathing and drinking to address particular maladies. ${ }^{89}$ 


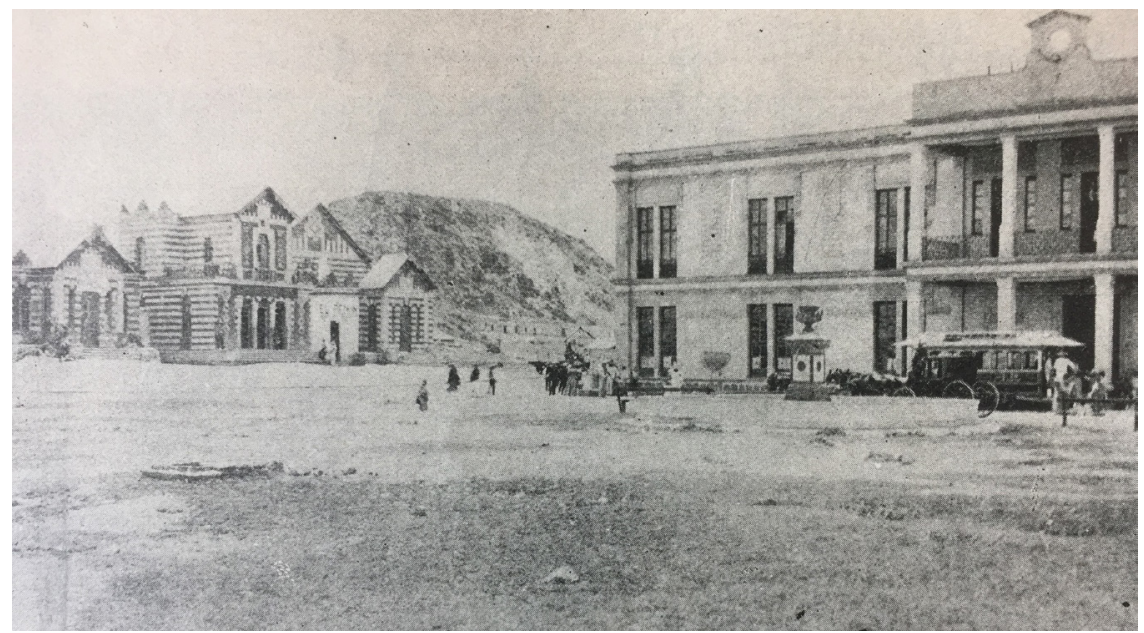

Figure 12. "Edificios de 'El Peñón.” El Mundo Ilustrado 2, no. 12 (1906). With permission of Universidad Nacional Autónoma de México, Hemeroteca Nacional de México, Fondo Reservado.

At 11:00 a.m. on November 31, 1892, a caravan of horse-drawn coaches rolled up in a salty, dusty cloud before the sparkling Victorian buildings at Peñón de los Baños. Two hundred formally dressed men, most of them doctors, made their way into the brand-new bathhouse and bottling plant situated at the foot of a rocky outcropping in the dry bed of Lake Texcoco. The physicians were from Mexico and the United States, and conversed in Spanish, English, and French. They were met by a cadre of some of the most influential figures in Mexico, including the owner of the installations, President Porfirio Díaz's father-in-law, Manuel Romero Rubio, and Díaz's personal doctor, Eduardo Liceaga. The foreigners were deeply impressed to find such a refined and sumptuous establishment, reminiscent of the luxurious spas of Europe, on the forlorn outskirts of Mexico City. They reviewed the marble baths, examined the hygienic bottling plant, and strolled through the richly appointed hotel before making their way back to the coaches for the sevenkilometer ride to the Castillo de Chapultepec, where they were received in the Yellow Room by Liceaga and the president of the Republic himself.

Source: Liceaga 1892: 3, "Report" 1893, "American Public Health Association."

Peñón was one of a small number of hot springs spas built in Mexico during the Porfiriato. After 1884, the railroad that passed through Aguascalientes brought visitors to its new bathhouses, and the Topo Chico bathhouse near Monterrey was erected in the 189os, together with a solid and elegant hotel (see chapter 7 ). 
Porfirio Díaz ordered studies conducted of the springs at Tehuacán, which led to the development of the Balneario del Riego and other bathhouses. ${ }^{90}$ As we have seen in chapter 5 , taking the waters in mineral springs was part of a wider upsurge in bathing and swimming fueled by the perception of hydraulic opulence associated with the artesian well. Bathhouses and mineral springs resorts multiplied over the next fifty years, but hygienic bathing slowly shifted from a public, social activity to a private, individual one, carried out increasingly within the confines of people's homes. Mineral waters bathing remained a social activity, but lost much of its medical rationale as therapy gave way to leisure as the principal rationale of the business of bathing.

\section{FROM BATH TO SHOWER}

"Hygiene and therapy fight for dominance in hydrology," Secundino Sosa announced in $1889 .{ }^{91}$ In the nineteenth century, chemistry, long the protagonist in the science of water and public health, slowly ceded ground to biological views of the importance of microorganisms, marking a similar movement away from treating bodies by exposing them to minerals in waters, and toward protecting bodies from the bacteria in the liquid. Liceaga, Lobato, Sosa, and many other Porfirian doctors held a therapeutic understanding of the efficacy of waters that was based in chemistry, and sought to promote and profit from European traditions of mineral springs bathing. But the new attention to microbiology was changing people's relations to water, and to each other. Instead of a medium for mineral treatments, water increasingly came to be seen as a carrier of contagious microbes. The contradiction between cure and contagion was sharpened by the idea that bathing could also promote hygiene and health by washing away biological contaminants.

The shower, taken individually, was seized upon as the way to benefit from the cleansing effect of water while ensuring that the water did not move microbes from one body to another. Showers produced a constant circulation of water, and like flushing, appealed to sanitarians preoccupied with stagnation. During the Porfiriato they were increasingly viewed as the most modern, healthful form of bathing. In 1885, a traveler in Mexico commented that the "bathhouses with showers, already common in Mexico, are challenging the bathhouses with tubs and placeres that are so common in this country, where all social classes frequently bathe." ${ }^{22}$ With showers in the public baths, the scene described with horror by Antonio García Cubas of a poor mother bathing her entire family in the same tub of water would be erased. ${ }^{93}$

The resurgent field of hydrotherapy also promoted the displacement of bathtubs by showers. Hydrotherapy held that it was the physical action of water on the body, rather than the minerals of chemicals contained by the water, that was therapeutic. This viewpoint gained strength from the knowledge that minerals suspended in water were actually not absorbed by the skin. In Mexico, popular 
hydrotherapy, or hydropathy, had been rejected by many doctors as an empirical, unscientific practice in the 1840 s, but medical students continued to submit theses on "scientific hydrotherapy" for the professional examination at the National School of Medicine throughout the last half of the century. ${ }^{94}$ The "heroic method of cold baths" inherited from the hydropathy of Priessnitz and others enjoyed a resurgence between 1890 and 1910 in many countries; first Germany and Austria, then the United States, Mexico, and elsewhere. Columbia University even dedicated a faculty chair to hydrotherapy, the first in the hemisphere. ${ }^{95}$ Hydrotherapy was applied by graduates of the National School of Medicine in the new General Hospital in Mexico City. ${ }^{96}$ Part of the success of this medical tradition came from its ability to incorporate the latest scientific discoveries, such as electricity and radiation. ${ }^{97}$ In 1901, for example, Samuel Morales opened an ultra-modern "electro-medical" bathhouse in Mexico City, offering shock treatments in cold and hot water baths, dry-shocks, $x$-rays and massages..$^{8}$

Following the initial inspiration of Priessnitz in the 1840s, and Fleury in the 1870s (Lugo 1875), hydrotherapists elaborated an increasingly complex array of hoses and showers to direct water at particular parts of the body. By 1900, such showers were present in hospitals and baths around the world-the Orthopedic Hospital in Philadelphia; Elizabeth Hospital in Washington, DC; Massachusetts State Hospital in Danvers; and the Riverside Baths in New York City-and were installed by Eduardo Liceaga at the new General Hospital in Mexico City (1905). Liceaga also promoted hydrotherapy from his chair at Mexico's National School of Medicine. ${ }^{99}$ The psychiatric hospital "La Castañeda," opened in 1910, deployed hydrotherapeutic showers to treat mental and emotional disorders, as did Bellevue Psychiatric Hospital in New York.

The turn to the hydrotherapeutic shower was a turn away from the bathhouse culture of the late nineteenth century. Victor Macías-González (2012) shows that Porfirian bathhouses contained varied social spaces that offered a wide range of leisure activities, from swimming pools, barbers, and massages to reading rooms and restaurants, as well as numerous private rooms that facilitated homoerotic encounters among middle class and elite Mexican men. These bathing establishments often embraced an imaginary of opulence and leisure associated with Roman and Turkish baths. But in the face of growing homophobia propelled by the notorious persecution of the " 41 " in 1901, bathhouse operators such as the owner of the San Felipe Baths stressed "order and morality," limiting physical and social interactions and focusing activity on the hygienic act of washing quickly in strictly individualized spaces. The revolution (1910-20) added to this tendency with a critique of the decadence of the Porfirian bourgeoisie, and the promotion of ideals of efficiency, action, and heterosexual virility. Revolutionary reformers in the Departamento de Salubridad lauded the shower as a fast, efficient way to wash the body that eliminated the sensuality and connotations of homoeroticism carried by placeres and other immersion baths. ${ }^{100}$ In the twentieth century, the 
policing of sociality and sexuality in the bath compelled a transition from immersion to showering.

The extension of hydraulic infrastructure into the household generalized the shower and individualized bathing. Widespread everyday bathing only became possible with the opulence of water that began with the artesian wells after 1850. Bathhouses grew in popularity in the last decades of the nineteenth century, but this expansion of social bathing was matched after 1910 by private bathing as huge volumes of new water were delivered by the aqueduct from the springs of Xochimilco to homes in the growing suburbs along the Paseo de la Reforma. The Colonia Doctores, Colonia Roma, Colonia Juárez, and Colonia Condesa were obliged by the 1891 Sanitary Code (passed by Eduardo Liceaga when he directed the Consejo de Salubridad) to include sewers and potable water lines, and all new housing was to be delivered water individually. ${ }^{101}$ People would no longer rely on collective fountains and wells that had served the city's inhabitants for centuries.

The shower was looked upon by sanitary reformers as the most progressive and modern mode of bathing and the "most commonly used in the civilized countries." 102 It was hygienic, therapeutic, and allowed the bather to adjust the water temperature, thus eliminating interactions with bathhouse workers and servants. In the 1920 s the Departamento de Salubridad passed Sanitary Engineering and Potable Water regulations that required that each apartment in a building or a vecindad have an individual water meter, and that showers be installed in all private housing, new and old. ${ }^{103}$ In the draft of the Regulations for Public Baths written in 1924, the Departamento de Salubridad required that public pools be emptied, washed, and refilled with new water twice a week, and swimmers were to shower before entering the pool. Public baths were obliged to provide sponges, soaps, and other implements to individual bathers and these items were to be disposable. Bathhouses dedicated to hygienic rather than medicinal bathing were required to substitute the placer or tub with showers in private rooms. ${ }^{104}$ In medicinal, mineral springs bathhouses such as Aragón and Peñón, the Departamento de Salubridad allowed bathing in tubs, but required them to be cleaned daily and forbid the use of bathwater by more than one person. ${ }^{105}$

The business of bathing changed over the first few decades of the twentieth century, as more wealthy and middle-class Mexicans took showers at home, abandoning the bathhouses to a swelling urban underclass. Bathhouse owners argued that Mexico's bathhouses were already better than those of New York, Chicago, Paris, and London, and that the additional expenses of installing showers were unnecessary and would make bathing too costly for the "the middle and humble class, employees and workers who form the great majority of the users." ${ }^{106}$ The Alberca Pane, the once-thriving establishment where Carlos Pacheco, Porfirio Díaz, and a host of other elite customers met to swim, soak, steam, and socialize, was apparently unable to pay for the required remodeling, and asked for an exemption from the new rule to install showers. ${ }^{107}$ 
Salubridad's effort to reshape bathing ran into opposition from owners of baths, real estate developers, and landlords. The department convened a meeting between government officials, property owners and developers, and sanitary engineer Roberto Gayol. The young Salubridad officials insisted that the landlords and developers be required to install a shower for every dwelling, and one shower for every twenty people living in collective dwellings such as vecindades and old houses that had been divided into apartments. The property owners protested that costs would be prohibitive, and that such measures were wasted on a public that was not particularly clean. Salubridad countered that showers were needed to create new habits of hygiene among the poor, but that bathing itself did not need promotion: the bathhouses were thronged, more than ever before, by working-class and poor city dwellers. Rather, the new habit they sought to promote was showering at home, and it was indeed adopted en masse during the twentieth century, displacing public bathhouses almost entirely.

\section{CONCLUSIONS}

Roberto Gayol eased into his chair at the new headquarters of Public Health, built on the Paseo de la Reforma at the edge of the Bosque de Chapultepec, and admired the modern art-deco architecture. Gayol remembered when this part of the city was still open fields, when he directed the construction of water and sewer lines that serviced the new middle-class neighborhoods erected after 1900. All those houses had running water and bathrooms, and now the young engineers of Public Health were attempting to bring these amenities to the rest of the folks in Mexico City. He admired their revolutionary zeal to build a new, more integrated nation, but had his doubts. The Sanitary Engineering Code they presented at the meeting made showers obligatory in all dwellings, but the landlords and developers at the table fought the measure. Gayol agreed with the landlords that it would be too expensive and difficult to retrofit the colonial period buildings in the city center, but he did not second their opinion that poor Mexicans who lived in older sections of the city in vecindades [tenement blocks] and apartments without plumbing "were just plain dirty." Showers should be available to those people too, and he agreed with the licenciados of Public Health that the infrastructure would promote good habits of hygiene. At 73, he had lived long enough to recognize that the revolutionary effort to create a culture of bathing around household showers was the logical conclusion of the modernizing hydraulic engineering project that he had begun fifty years earlier.

Source: AHSS, FSP, SSJ, Caja 21, Exp. 9, Transcript of Meeting (April 9, 1930).

After 1850, bathing changed in important ways, a result of hydraulic opulence, capital looking for profits, and new scientific knowledge of chemistry and 
microbiology. The idea of water moved toward that of a uniform substance, delivered through encompassing infrastructures. But at the same time, everybody recognized a diversity of tastes and qualities among the different water sources that supplied Mexico City. By 1858 the hard water of the Chapultepec springs and the soft water of the aqueduct from the Santa Fe springs were supplemented by wells in Bucareli, Los Migueles, and the Calle de Cordobanes. These waters and others were analyzed by chemists who described their temperature, density and levels of oxygen, carbonic acid, calcium sulfate, bicarbonate of calcium, and other contents. ${ }^{108}$ Waters had always been recognized for their various qualities (gorda, delgada, gruesa, dulce, salada, hedionda, azufrosa, etc.), and these distinctions could increasingly be explained by chemists in terms of content of minerals, gases, organic matter, and the like. Mexican chemists, like their European counterparts, understood that different waters had different uses: "some were destined to satisfy household needs, others for industrial ones, and not a few for restoring the health of man." 109 Some waters, such as those from the artesian wells near San Lázaro, were unpalatable and smelled badly because of dissolved gases, and were not considered useful. In an interesting paradox, waters continued to be viewed as plural and specific because scientists and planners sought to combine them and convert them into a singular substance.

The sciences of chemistry, microbiology, and medicine grappled with the specificity of all these waters. The discovery by Pasteur and his contemporaries of the microscopic animals responsible for fermentation as well as sickness placed medicine on a new footing, as health was resignified as cleanliness, and cleaning made into a battle against germs. The hegemony of microbiology and hygiene rebalanced the range of acceptable purposes for bathing, but it was a fragile hegemony. Water used for cleanliness was also a threat to hygiene, as it could just as easily bring bodies into contact with those elements that were considered dangerous. Bathtubs and soaking gave way to showers and rinsing, ensuring that once washed from the skin, "dirtiness" was banished rapidly down the drain. Newly perceived dangers of baths came to compete with long-held ideas about the therapeutic benefits of water, and the cleansing flow of the shower stood out as the most hygienic interaction with the liquid.

Despite the rise of the hygienic understanding of water, the therapeutic, ludic, and recreational dimensions of bathing were not displaced by the urge to clean, but rather flourished as a parallel set of activities. The long shift to the shower and the rise of the singular concept of sanitized water did not eradicate the engagement with diverse waters. The increased flow of capital toward the business of bathing was accompanied by an evolving discourse and practice of water therapy that swirled at the fluid edge of medical orthodoxy. Bathhouses in the late nineteenth and early twentieth centuries such as the Alberca Pane offered an ever-wider array of bathing experiences: hot, lukewarm, and cold waters, plunge baths, steam, dry saunas, placeres, swimming pools, inhalation chambers, drinking fountains, 
and showers of all different kinds. After 1920 the solitary household shower with public water grew to be the most important daily contact most city dwellers had with the liquid, but heterogeneous waters and water cultures lived on in the hot springs resorts and bottling plants that flourished throughout Mexico during the twentieth century. 